PROBLEMS

OF MANAGEMENT

IN THE $21^{\text {st }}$ CENTURY

Vol. 9, No. 2, 2014

\section{$\left.{ }^{140}\right]$ THE IMPACT OF CHANGE MANAGEMENT ON JOB SATISFACTION OF EMPLOYEES IN GHANA'S BANKING SECTOR}

\author{
Noble Osei-Bonsu \\ Central University College, Tema, Ghana \\ E-mail: lenoble25@yahoo.com
}

\begin{abstract}
Employee job satisfaction is pertinent and critical in the change management process of contemporary organizations. The objectives of this study are to assess the extent of employee involvement in the change management processes, assess the impact of change management on employee job satisfaction and thirdly, attitude of employees after organizational change. A descriptive survey research design was employed to administer a self-designed questionnaire consisting of open and closed-ended items to one hundred and forty respondents using simple random sampling. Closed-ended items were measured on a five-point Likert scale. Data was analysed using SPSS and presented in descriptive form. The main findings indicate that employees' involvement in the process was limited to provision of adequate information. It was also revealed that generally, the change had a positive impact on employees'job satisfaction. Finally, employee attitudes after the change were found to be positive. Interestingly, respondents disagreed with the issue of high level of trust after the change process. In view of the findings, it is recommended that management should encourage employees' maximum participation in the process through adequate representation on change management committees.
\end{abstract}

Key words: attitude, change management, employee involvement, job satisfaction, organizational change.

\title{
Introduction
}

The recent global economic downturn among other internal and external challenges has created a platform for business organizations to strategically position themselves in order to survive the competitive environments within which they operate. As a result, businesses across the world are constantly changing their operations and re-strategizing to overcome the stiff competition existing in the business world. It has been observed that seven important environmental challenges to businesses in recent times include rapid change, rise of the internet, workforce diversity, legislation, evolving work and family roles, globalization, skill shortages and rise of the service sector (Gomez-Meija, Balkin, \& Cardy, 2007, p.4). Interestingly, change is an indispensable phenomenon in the life of every organization. Thompson, Strickland \& Gamble (2010) also observe that in the current business environment, many companies operate in industries characterized by rapid technological change, short product life cycles, competitive manoeuvres, fast-evolving customer requirements and expectations, all of which occur in a manner that creates swirling market conditions and uncertainty. In fact, Armstrong (2003) identifies two main types of change: strategic and operational change. According to him, strategic change deals with broad, long-term and organization-wide issues such as strategic vision, mission and corporate philosophy. On the other hand, operational change relates to new systems, procedures, structures and technology that have immediate effect on work arrangements within a part of an organization. 
Undoubtedly, in recent times, the financial services sector all over the world has experienced a great deal of external pressures partly due to the global economic crisis, deregulation and advanced technology. As a result, some banks have had to embark on certain strategic moves including mergers and acquisition in order to be competitive. In Ghana for instance, the new capital requirements as part of the design of the universal banking concept started in 2003 among other issues, led to some mergers and acquisitions. For example, Bank of Baroda secured majority stake in Amal Bank Ltd. while Ecobank Transnational Incorporated acquired The Trust Bank Ghana Ltd. to become the largest bank (in terms of assets) in Ghana. The recapitalization reform in Ghana requires all banks to have a minimum capital of GH60million cedis. Another challenge facing the banking sector in Ghana is the, liberalization of the financial sector by the central bank which led to an influx of new banks and thus, further intensified competition in the banking sector. Presently, the number of banks which have been licensed to operate by the central bank as at April 2013 are over 25. This situation among others has put a number of banks under intense pressure to perform thus, necessitating frequent organizational changes to keep up the pace.

It is important to stress that in change management processes, new systems are introduced, procedures and structures are changed, roles may be assigned and reassigned, and staff rationalization could be effected. All these could have immediate and significant effect on employees within the organization and if not properly managed, may lead to work attitude challenges including job dissatisfaction. In practise, it's been found that employees often respond negatively to change due to increased work pressure and stress often associated with the change process (Self \& Schraeder, 2009; Jones et al., 2008). In addition, research has found that employees are also concerned about the magnitude of change and how it impacts on their job (Bartunek et al., 2006). Therefore, the extent of planning and the entire management of a change process play an important role since it is a major concern of employees (Korsgaard et al., 2002). According to Griffin et al., (2004), planning by management enhances employees' change efforts and psychological wellbeing.

Emphasis must be laid on the fact that the type of change management carried out in the particular organization under study had to do with restructuring of work processes, merging of job schedules and introduction of new schedules. In the light of these issues, the study intends to assess the impact of the change management process on the job satisfaction of employees in Ghana's banking sector with three main research questions in focus.

1. What is the extent of employee involvement in the change management process?

2. What is the level of employee job satisfaction after the change process?

3. What is the attitude of employees after the change process?

\section{Literature Review}

The organizational change and job satisfaction literature suggests that an individual's reactions to change could be influenced by individual characteristics and aspects of the change situation (E.g. Judge et al., 1999; Wanberg and Banas, 2000). Indeed several studies have also indicated that many determinants such as, communications, job demands, job knowledge and skills, participation among others, prevail in support of change management programmes (Eby et al., 2000; Cunningham et al., 2002; Chawla and Kelloway, 2004; Madsen et al., 2005; Rafferty and Simons, 2006). Similarly, research indicates that effects of organizational change depend on the nature of the change (Dent \& Goldberg 1999) as well as the context in which change occurs (Wanberg and Banas 2000; Oreg 2006). For example, Oreg (2006) found a negative association between employee resistance to change and trust in management. In other words, as employees' trust in management increases, their likelihood of resisting change reduces.

\author{
PROBLEMS \\ OF MANAGEMENT \\ IN THE $21^{\text {st }}$ CENTURY \\ Vol. 9, No. 2, 2014 \\ 141
}


Noble OSEI-BONSU. The Impact of Change Management on Job Satisfaction of Employees in Ghana's Banking Sector

PROBLEMS

OF MANAGEMENT

IN THE $21^{\text {st }}$ CENTURY Vol. 9, No. 2, 2014

142

Employee Involvement and Job Satisfaction during Organizational Change

Even though research has found that employees often respond negatively towards change due to increased work pressure and stress (Jones et al., 2008; Self and Schraeder, 2009; Pech and Oakley, 2005), according to Griffin et. al., (2004) planning by management tends to enhance employees' change efforts and psychological well-being. This implies that the more efforts are made to plan change in advance, the more the change becomes predictable for employees. In addition, research indicates that effectively managing employees' psychological transition is vital to achieving organizational change (Lazarus \& Folkman 1989) since poor management of the transition is associated with feelings of threat, frustration and anxiety (Nielsen et al., 2007).

For instance, there is evidence to show that when explanation is provided for a decision, it increases perceptions of justice and leads to more favourable reactions toward the organization (Singer, 1993; Greenberg, 1990; Tyler \& Bies, 1990). Research has examined the effects of a variety of information-related constructs on employee adjustment. In one such study, Schweiger and DeNisi (1991) observed that providing employees with realistic communication about an impending merger reduced the dysfunctional outcomes associated with the organizational change program. Similarly, Shaw et al., (1993) found that open communications with others was correlated with job satisfaction for 110 employees about to experience the divestiture of AT\&T into a series of independent companies. A follow-up one year later also revealed that open communications was predictive of employees' attitude towards the divestiture, job satisfaction and organizational commitment.

In addition, these findings have been corroborated in a recent study by Goris (2007) who found that employees who report higher levels of communication satisfaction tend to be more satisfied with their employment situation (Goris, 2007) and that other factors such as personal feedback and communication climate are also strongly related to job satisfaction. By extension, one could deduce that when employees express satisfaction with the level of communication during organizational change, they are likely not to react negatively. This could probably result from the fact that employees who are satisfied with communication regarding the change process may feel a sense of importance as a result of which their attitude towards the change would be positive. Indeed others suggested that when a change is handled well by the management, it does not only increase organizational effectiveness, but it also leads to desirable satisfaction-related personal reactions, such as improvements in perceived fit (Caldwell et al., 2004) and organizational commitment (Fedor et al., 2006).

\section{Attitude, Trust and Organizational Change}

Studies have shown that trust in leaders is an important element of organizational change, either as an antecedent or consequence of relationships at work (Saunders and Thornhill, 2003; Neves and Caetano, 2009). For instance, Lester and Kickul (2001) found that in a 32-item list of psychological contract valued most by employees, participants ranked trust and respect, open and honest communication as second and third respectively in importance. According to Mollering (2001, p.412), trust develops from favourable expectations based on interpretations of reality aided by a suspension of disbelief and a leap of an individual's faith. Research has also suggested that key attributes of employee participation, such as open communication, expressing new ideas, shared vision and common direction, as well as mutual respect, are key elements in fostering trust and managing organizational change (Nyhan, 2000). In addition, inclusion and participation of employees into decision-making processes also indicates both the organization's and management's trust in their employees (Erturk, 2008, p467). Similarly, studies have revealed that among others, one of the antecedents of perceptions of trust in the organization 
is contributions from employees (Rhoades et al., 2001; Husted and Michailova, 2002). This implies that employees may develop a certain trust for management and the organization when they feel they are valued, as well as partakers and contributors to organizational decisions. In effect, their trust in management may be affected should they experience non-involvement or perceive that their contributions don't matter. For instance, Lines et al., (2005) discovered that trust in management increases through participation in decision-making but decreased when employees experienced emotional strain. It must be pointed out that the issue of trust is linked to the perception of fairness as demonstrated by Frazier et al. (2010) who found a strong relation between perception of fairness and trust in immediate supervisor and higherlevel management. As a result of these findings, it is expected that in managerial decisions regarding change, consideration would be given to the effect on employees and not only how it affects the organization's performance.

\section{Methodology of Research}

The study is descriptive in nature and uses questionnaire to collect data. A total of 140 employees made up of 79 males and 61 females were selected from a public bank in Ghana using simple random sampling. The respondents were sampled from ten randomly selected branches in the capital city, Accra out of a total number of 23 in the city, due to the cosmopolitan nature of the location and also based on considerations of proximity to the researcher. Out of the total number of respondents, 84 were junior staff, 51 were senior staff and 5 were middle management staff. In addition, respondents ranged between the ages of 18 and 57 and had worked with the bank for at least a year.

Data for the study were collected using a self-designed questionnaire that took account of the research objectives. The questionnaire is made up of four sections including demographic information, extent of employee involvement in the change management process (4 statements), level of employees' job satisfaction (6 statements) and attitude of employees after recent change (4 statements). For example, job satisfaction statements include: "I am still satisfied with my job even after the change and "I feel comfortable and secured on my job". Statements on employee involvement in the change management process include: "Employees were adequately represented on the change management committees" and "The organization provided employees with adequate information and education on the change processes". For attitude of employees towards the recent change, statements such as:" The change has generated positive employee attitudes" and "There is a high level of trust in the organization". All statements regarding extent of employee involvement in the process, level of job satisfaction resulting from the change and attitude towards the change are measured on a 5-point Likert scale ranging from 'Strongly disagree' to 'Strongly agree' where the former is interpreted as 1 and the latter as 5. It must be indicated that Cronbach's Coefficients of alpha for the job satisfaction, employee involvement and employee attitude scales used in the questionnaire are $0.81 ; 0.76$ and 0.72 respectively. In relation to data collection procedure, after randomly selecting the branches and identifying the respondents, the questionnaires were distributed with the help of a research assistant. The respondents were given one week to respond to the questionnaires after which the questionnaires were retrieved with the help of the research assistant for analysis. Data was sorted for fully completed questionnaires and analysis was carried out using SPSS as presented in the results section. 
Noble OSEI-BONSU. The Impact of Change Management on Job Satisfaction of Employees in Ghana's Banking Sector

PROBLEMS

OF MANAGEMENT

IN THE $21^{\text {st }}$ CENTURY Vol. 9, No. 2, 2014

144

\section{Results of Research}

The study set out with three objectives in mind, that is, to find out the impact of change management on employees' job satisfaction, the extent of employees' involvement in the change management process and the attitude of employees after the change process. Below is a presentation of the findings.

Table 1. Descriptive statistics showing extent of employee involvement in the change management process.

Level of Employee Involvement in Change Management $\quad$ Mean $\begin{aligned} & \text { Standard Devia- } \\ & \text { tion }\end{aligned}$

My organization provided employees with adequate information and education on the change processes and action plan

\section{$4.20 \quad 0.876$}

\begin{tabular}{lll}
\hline New managerial initiatives were much published in the course of time & 4016 & 0.950 \\
\hline Employees had the ability to influence managerial actions & 3.14 & 1.025 \\
\hline Employees were adequately represented on change management committees & 2.38 & 1.293 \\
\hline
\end{tabular}

Source: Survey Data, 2013

Table 1 indicates that there was greater level of agreement by respondents regarding provision of adequate information on the change process and publicity of new managerial initiatives $($ mean $=4.20,4.16 \mathrm{SD}=0.876,0.95)$ respectively. Respondents were of the opinion that the change process as well as initiatives of management was fairly communicated to them. On the issue of employees' ability to influence managerial actions, results indicate that there was uncertainty among respondents (mean $=3.14, \mathrm{SD}=1.02)$ to the effect that they were not sure of their level of influence in the decisions taken by management. There was however disagreement with the statement that they were adequately represented on change management committees $($ mean $=2.38 ; \mathrm{SD}=1.29)$. This shows that even though employees were adequately informed about the change processes and action plan, as indicated by their level of agreement, the level of participation in the entire process was perceived to be low.

Table 2. Impact of change management on employee job satisfaction.

\begin{tabular}{|c|c|c|}
\hline Impact of Change Management on Job Satisfaction & Mean & Standard Deviation \\
\hline After the change management I feel proud to be part of this organization & 4.23 & 0.871 \\
\hline I am still satisfied with my job even after the change & 4.20 & 0.833 \\
\hline I feel comfortable and secured on my job even after the change & 4.12 & 0.825 \\
\hline $\begin{array}{l}\text { I strongly align with the work policies of this organization resulting from the change } \\
\text { management }\end{array}$ & 4.22 & 0.813 \\
\hline There is adequate opportunity for career advancement and self-development & 4.37 & 0.906 \\
\hline After the change, my job role is commensurate with my skill and knowledge & 3.18 & 0.543 \\
\hline
\end{tabular}

Table 2 reveals that after the change management process, respondents felt proud to be part of the organisation and also expressed increased job satisfaction levels respectively as indicated in table 2 (mean $=4.23 ; 4.20 \mathrm{SD}=0.87 ; 0.83)$. In addition, they felt secured in their 
jobs and also strongly aligned with the organization's policies (mean=4.12; 4.22 SD=0.82; 0.81). Again, from the analysis above, it is revealed that respondents agreed to a large extent on the issue of adequate opportunity for career advancement and self development (mean=4.37; $\mathrm{SD}=0.91)$. However, one interesting finding was that there was a bit of uncertainty regarding how the job roles commensurate with their skill and knowledge (mean=3.18 SD=0.54). Perhaps with the restructuring of work processes, respondents were not sure how their skill matches the new restructured arrangement.

\section{Table 3. Descriptive statistics of attitude of employees towards the recent change.}

\begin{tabular}{lll}
\hline Attitude of Employees after the recent change & Mean & Standard Deviation \\
\hline The organisational change has resulted in reduced absenteeism & 4.37 & 0.906 \\
\hline The change has reduced labour turnover & 4.19 & 0.849 \\
\hline The change has generated positive employee work attitude & 4.16 & 0.849 \\
\hline There is a high level of trust in the organisation & 2.17 & 0.345 \\
\hline
\end{tabular}

Source: Survey Data 2013

This study also examined the attitude of employees towards the recent change. Results of the study revealed that after the change process, there has been reduction in both absenteeism and employee turnover (mean=4.37; $4.19 \mathrm{SD}=0.90 ; 0.88$ ). Respondents were of the view that due to the objectives, directions and new policies of the organization, the issue of employee absenteeism has been critically dealt with, as measures and effective enforcement mechanisms have been put in place. In addition, the analysis revealed that the change has generated positive employee work attitudes (mean=4.16; $\mathrm{SD}=0.849$ ). However, respondents were of the opinion that there is low level of trust in the organisation as a result of the change (Mean=2.17; $\mathrm{SD}=0.34$ ). This could result from the fact that respondents were quite uncertain about their ability to influence management actions as observed in the employee-involvement analysis (Mean =3.14 $\mathrm{SD}=1.02$ ). Discussion of the above results is presented below.

\section{Discussion}

Below is a discussion of the research findings in relation to the research questions set out by this study. With regards to the first research question, it could be argued that the perception of inadequate representation on change management committees probably accounts for respondents' uncertainty regarding their ability to influence managerial actions. It could be deduced that perhaps respondents felt a sense of inadequate representation as a result of which they felt they couldn't influence certain decisions of management regarding the change process. The findings generally indicate that employee involvement in the entire change management process was limited to adequate information and publicity of new managerial initiatives which showed greater level of agreement among respondents. Research has indeed found that among other determinants, communication and participation tend to influence organizational change programmes (Eby et al., 2000; Cunningham et al., 2002; Chawla and Kelloway, 2004; Madsen et al., 2005; Rafferty and Simons, 2006). What this finding may suggest is that perhaps managers of change should not just communicate information on the process to employees, but should take into serious account their representation on various change management committees to enhance perception of involvement in the entire process. 
Noble OSEI-BONSU. The Impact of Change Management on Job Satisfaction of Employees in Ghana's Banking Sector

PROBLEMS

OF MANAGEMENT

IN THE $21^{\text {st }}$ CENTURY Vol. 9, No. 2, 2014

146

On the issue of the impact of the change management process on employees job involvement, it could be deduced that overall, the respondents' level of job satisfaction after the change process was high. Even though some research findings indicate employees' negative reactions to change (Pech and Oakley, 2005; Jones, L., Watson, B., Hobman, E., et al., Bordia, P., Gallois, C. \& Callan, V. J. (2008;), further findings also indicate that communication satisfaction and communication climate are related to employee job satisfaction (Goris, 2007; Downs and Adrian, 2004, p.155). This study's finding is consistent with earlier findings (Shaw et al., 1993) indicating that open communications correlated with job satisfaction for employees about to experience the divestiture of a company into series of independent companies. In table 1 , respondents indicated greater level of agreement with the statement regarding provision of adequate information and education about the change processes and action plans. This may probably explain respondents' overall satisfaction with their jobs after the change process notwithstanding the uncertainty regarding how the job roles commensurate with their skill and knowledge (mean $=3.18 \mathrm{SD}=0.54)$.

With regards to the third research question, it must observed that findings regarding reduced absenteeism, reduced labour turnover and positive work attitudes are consistent with that of (Greenberg, 1990; Tyler \& Bies, 1990; Singer, 1993) who found evidence to show that when explanation is provided for a decision, it increases perceptions of justice and leads to more favourable reactions toward the organization. This is further supported by other findings which established that employee attitudes and outcomes of organizational change initiatives depend in part, on effective internal communication practices (Proctor and Doukakis, 2003; Kitchen and Daly, 2002). On the issue of low level of trust, it could be that because they were not adequately represented in the change management committees, perhaps they felt the level of participation was low thus, affecting their trust in the organization. According to Nyhan (2000), key attributes of employee participation, such as open communication, expressing new ideas, shared vision and common direction as well as mutual respect, are key elements in fostering trust and managing organizational change. Therefore, employees who for instance may feel that they couldn't influence certain decisions through expression of new ideas may exhibit low levels of trust. This finding is consistent with findings of Lines et al., (2005) who discovered that trust in management increases through participation in decision-making.

\section{Limitations and Future Research}

The main limitation of this study is the use of a single organization. This may introduce a potential for same-source bias. The ideal situation was to have included other financial institutions and branches outside the capital city of Accra, to allow for greater geographical representation. Future research could improve on this study by expanding the geographical representation to include other financial institutions. In addition, future research could consider increasing the sample size from the current sample of 140 to enhance the study's generalizability. Finally, future research could also consider the use of a standardized scale for job satisfaction as an improvement on the self-developed questionnaire used in this study. These limitations have the potential to affect the generalizability of the study's findings. These limitations notwithstanding, findings from the study may have implications for the management of change, particularly, when it comes to involvement of employees in the entire process. 


\section{Implications of the Study}

This study has revealed some interesting findings which may have implications for organizations in the way change management processes are carried out. First of all, on the issue of extent of employee involvement in the change process, findings revealed that the level of involvement as perceived by respondents was limited to adequate information and publicity and not necessarily total involvement in the decision process. As a result, employees might feel that they are "informed observers" and not "informed participants". This perhaps reflected in their responses of uncertainty on the issue of their influence of managerial actions regarding the change, having disagreed that they were adequately represented on change management committees. This has implication for management because with such perception, employees may not have a sense of part-ownership of the entire change process even though they may appreciate the fact that they have been given adequate information. It is recommended that as much as employees should be adequately informed on issues, it is prudent to involve them in the process and also take some of their suggestions on board through their representatives for them to have a feeling that they are part of the decision-making process. Secondly, even though employees generally reported higher level of job satisfaction as presented in table 2, they disagreed with the fact that there was high level of trust in the organization (table 3 ). This has implication for management and organizations because on the issue of trust, studies have shown that among other antecedents, contributions from employees tend to influence perceptions of trust in the organization (Rhoades et al., 2001; Husted \& Michailova, 2002). It could be argued that because employees perceived that they did not have adequate representation and influence in the entire process, they couldn't contribute meaningfully to the process thereby affecting their level of trust. These findings have brought to the fore the need for organizations to review their change management processes to ensure adequate representation and full participation of employees in the entire process and thus, enhance perception of transparency which may in turn, engender trust.

\section{Conclusions}

The study set out with three research objectives in mind. First of all, to establish the extent of employees' involvement in the entire change management process, secondly, to determine the impact of the change process on employees' job satisfaction. Finally, to assess employees' attitude after the change management programme. Findings from the study revealed that employees' involvement in the process was perceived to be limited to provision of adequate information and publicity of management's initiatives. There was, however, disagreement with respect to representation on change management committees, indicating low level of employee involvement. With regards to impact of the change management on employee job satisfaction, the findings indicated a high level of agreement for all the items. The only uncertainty had to do with how employee job roles commensurate with their skills and knowledge. Generally, the responses indicate a positive impact on job satisfaction. On the issue of employee attitude after the change process, it was realised that attitude of employees seemed quite positive with three of the four items attracting high levels of agreement to the statements. However, respondents disagreed with the statement about high levels of trust after the change process, reflecting in a lower mean score. Concluding, in view of these findings, management and organizations handling change (i.e. restructuring work processes) must ensure that employees are adequately represented on change management committees to enhance perception of transparency and improve level of participation. 
Noble OSEI-BONSU. The Impact of Change Management on Job Satisfaction of Employees in Ghana's Banking Sector

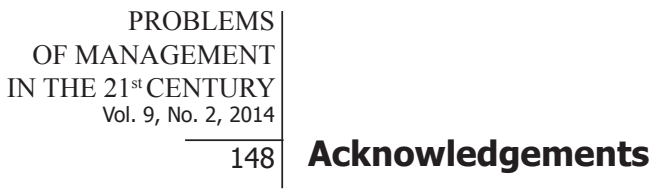

The author is grateful to Mrs. Lawrencia Owusu who assisted with data collection and all respondents for their participation.

\section{References}

Armstrong, M. (2003). A handbook of human resource management practice. ( $9^{\text {th }}$ Ed). London, UK: Jogan Page.

Bartunek, J. M., Rosseau, D. M., Rudolph, J. W., \& DePalma, J. A. (2006). On the receiving end: sense making, emotion and assessments of organizational change initiated by others. Journal of Applied Behavioural Science, 42 (2), 182 -206.

Chawla, A., \& Kelloway, E. K. (2004. Predicting openness and commitment to change. Leadership and Organization Development Journal, 25 (5/6), 485 -498.

Cunningham, C. E., Woodward, C. A., Shannon, H. S., \& MacIntosh, J. (2002). Readiness for organizational change: A longitudinal study of workplace, psychological and behavioural correlates. Journal of Occupational and Organizational Psychology, 75 (4), 377 -392.

Dent, E. B., \& Susan, G. G. (1999). Challenging resistance to change. Journal of Applied Behavioural Science, 35 (1), 25 -41.

Eby, L. T., Adams, D. M., Russell, J. E. A., \& Gaby, S. H. (2000). Perceptions of organizational readiness for change: factors related to employees' reactions to the implementation of team-based selling. Human Relations, 53 (3), 419 -442.

Ertuk, A. (2008). A trust-based approach to promote employees' openness to organizational change in Turkey. International Journal of Manpower, 29 (5), 462 -483.

Downs, C. W., \& Adrian, A. D. (2004). Assessing organizational communication: Strategic communication audits. New York, NY: The Guilford Press.

Fedor, D. B., Herold, D. M., \& Caldwell, S. D. (2006). The effects of change on employee commitment: a multilevel investigation. Personnel Psychology, 59 (1), 1 -29.

Frazier, M. L., Johnson, P. D., Gavin, M., Gooty, J., \& Snow, D. B. (2010). Organizational justice, trustworthiness and trust: A multifocal examination. Group and Organization Management, 35 (1), 39-76.

Gomez-Meija, R. L., Balkan, D. B., \& Cardy, L. R. (2007). Managing human resources. (5 th $^{\text {Ed). }}$ Upper Saddle River, New Jersey: Pearson Education Inc.

Goris, J. R. (2007). Effects of satisfaction with communication on the relationship between individual-job congruence and job performance/satisfaction. The Journal of Management Development, 26 (8), $737-752$.

Greenberg, J. (1990). Organizational justice: Yesterday, today and tomorrow. Journal of Management, $16,399-432$.

Griffin, M. A., Rafferty, A. E., \& Mason, C. M. (2004). Who started this? Investigating different sources of organizational change. Journal of Business and Psychology, 18 (4), 555 -570.

Husted, D., \& Michailova, S. (2002). Diagnosing and fighting knowledge-sharing hostility. Organizational Dynamics, 31 (1), 60 -73.

Jones, L., Watson, B., Hobman, E., Bordia, P., Gallois, C., \& Callan, V. J. (2008). Employee perceptions of organizational change: Impact of hierarchical level. Leadership and Organization Development Journal, 29 (4), 294 -316.

Judge, T. A., Thoresen, C. J., Pucik, V., \& Welbourne, T. M. (1999). Managing coping with organizational change: A disposition perspective. Journal of Applied Psychology, 84 (1), 107 -122.

Kitchen, P. J., \& Daly, F. (2002). Internal communication during change management. Corporate Communications, 7 (1), 46 -53.

Korsgaard, M. A., Brodt, S. E., \& Whitener, E. M. (2002). Trust in the face of conflict: the role of managerial trustworthy behaviour and organizational context. Journal of Applied Psychology, 87 (2), $312-319$.

Lazarus, R. S., \& Folkman, S. (1989). Manual for the study of daily hassles and uplift scales. Palo Alto, CA: Consulting Psychologists Press. 
Lester, S. W., \& Kickul, J. (2001). Psychological contracts in the twenty-first century: What employees value most and how well organizations are responding to these expectations. Human Resource Planning, 24 (1), 10 -21.

Lines, R., Selart, M., Espedal, B., \& Johansen, S. T. (2005). The production of trust during organizational change. Journal of Change Management, 5 (2), 221 -245.

Madsen, S. R., Miller, D., \& John, C. R. (2005). Readiness for organizational change: do organizational commitment and social relationships in the workplace make a difference? Human Resource Development Quarterly, 16 (2), 213 -233.

Mollering, G. (2001). The nature of trust: from George Simmel to a theory of expectation, interpretation and suspension. Sociology, 35, $403-420$.

Neves, P., \& Caetano, A. (2009). Commitment to change: contributions to trust in the supervisor and work outcomes. Group and Organization Management, 34 (6), 623 - 644.

Nielsen, K., Randall, R., \& Albertsen, K. (2007). Participants' appraisals of process issues and the effects of stress management interventions. Journal of Organizational Behaviour, 28, $793-810$.

Nyhan, R. C. (2000). Changing the paradigm: Trust and its role in public sector organizations. $A$ merican Review of Public Administration, 30 (1), 87 -109.

Oreg, S. (2006). Personality, context and resistance to organizational change. European Journal of Work and Organizational Psychology, 15 (1), 73 -101.

Pech, R. J., \& Oakley, K. E., (2005). Hormesis: An evolutionary predict and prepare survival mechanism. Leadership and Organization Development Journal, 26 (8), 673 -687.

Proctor, T., \& Doukakis, I. (2003). Change management: the role of internal communication and employee development. Corporate Communications, 8 (4), 268 -277.

Rafferty, A. E., \& Simons, R. H. (2006). An examination of the antecedents of readiness for fine-tuning and corporate transformation changes. Journal of Business and Psychology, 20 (3), 325 -350.

Rhoades, L., Eisenberger, R., \& Armeli, S. (2001). Affective commitment to the organization: The contribution of perceived organizational support. Journal of Applied Psychology, 86 (5), 825 $-836$.

Saunders, M. N. K., \& Thornhill, A. (2003). Organizational justice, trust and the management of change: An exploration. Personnel Review, 32 (3), 360 -375.

Schweiger, D., \& Denisi, A. (1991). Communication with employees following a merger: A longitudinal field experiment. Academy of Management Journal, 34 (1), 110 -135.

Self, D. R., \& Schraeder, M. (2009). Enhancing the success of organizational change: Matching readiness strategies with sources of resistance. Leadership and Organization Development Journal, $30(2), 167-182$.

Shaw, J. W., Fields, M. W., Thacker, J. W., \& Fisher, C. D. (1993). The availability of personal and external coping resources: Theirimpactonjobstress and employee attitudes during organizational restructuring. Work and Stress, 7, 229 -246.

Singer, M. (1993). The application of organizational justice theories to selection fairness research. New Zealand Journal of Psychology, 22, 32 -45.

Thompson, A. A. Jr., Strickland III, A. J., \& Gamble, J. E. (2010). Crafting and executing strategy: The quest for competitive advantage, concepts and cases. $\left(17^{\text {th }}\right.$ Ed). New York, NY: McGraw-Hill/ Irwin.

Tyler, T. R., \& Bies, R. J. (1990). Interpersonal aspects of procedural justice. In Carroll, J. S. ( ( E d . ), Applied Social Psychology and Organizational Settings, (pp. 77-78). Hillsdale, NJ: Erlbaum.

Wanberg, C. R., \& Banas, J. T. (2000). Predictors and outcomes of openness to change in a reorganizing workplace. Journal of Applied Psychology, 85 (1), 132 -142.

Advised by Constantin Bratianu, Academy of Economic Studies, Bucharest, Romania

Received: May 11, 2014

Accepted: August 15, 2014

Noble Osei-Bonsu

\section{PROBLEMS \\ OF MANAGEMENT \\ IN THE $21^{\text {st }}$ CENTURY \\ Vol. 9, No. 2, 2014}

